\title{
STRATEGI MANIPULASI PSIKOLOGI (PROPAGANDA) \\ DALAM UPAYA MENINGKATKAN MINAT MASYARAKAT TERHADAP PONDOK PESANTREN AL-KHOERIYAH CIBINGBIN.
}

\author{
Ammar Syahrial \\ Syahrial.ammar@gmail.com \\ Universitas Islam Al-Ihya Kuningan
}

\begin{abstract}
Absrtak
Propaganda merupakan alat atau cara komunikasi yang memiliki citra buruk di masyarakat. Hal ini terjadi akibat adanya sejarah yang panjang tentang kemunculan propaganda serta penggunaannya yang di salah gunakan sehingga mindset publik terhadap istilah propaganda menjadi buruk. Pada kenyataannya propaganda hanyalah sebuah teknik atau alat komunikasi, yang baik atau buruknya tergantung yang menggunakan alat tersebut dan tujuan yang hendak dicapainya. Dengan demikian propaganda bisa digunakan sebagai sarana yang untuk mempromosikan hal-hal yang positif termasuk diantaranya untuk mempromosikan pondok pesantren. Dengan pola propaganda atau manipulasi psikologi, diharapkan minat masyarakat terhadap pesantren lebih meningkat yang secara konsekwensi logis akan meningkatkan kuantitas dari peserta didik (santri) yang belajar (mondok) di pesantren.
\end{abstract}

Kata Kunci: Propaganda, Psikologi, Pondok Pesantren.

\begin{abstract}
Propaganda is a tools of communication that has a bad image in society. This occurs due to a long history of the emergence of propaganda and its misuse of use so that the public mindset towards the term propaganda becomes bad. In fact, propaganda is just a technique or communication tool, the good or the bad depends on who uses the tool and the goals it wants to achieve. Thus propaganda can be used as a means to promote positive things including promoting Islamic boarding schools. With the pattern of propaganda or psychological manipulation, it is expected that public interest in pesantren will increase which consequently will logically increase the quantity of students (santri) studying (mondok) at the pesantren.
\end{abstract}

Keywords: Propaganda, Psychology, Islamic Boarding School.

\section{Pendahuluan}

Istilah propaganda sering didengar atau dilihat dari berbagai sumber, baik dari buku, media visual dan media audio visual. Namun istilah tersebut selalu mendapatkan respon 
buruk, mayoritas masyarakat berasumsi negatif sehingga seringkali menjadi tabu untuk dibahas. Cap buruk yang menempel pada propaganda diakibatkan banyaknya pihak yang memanfaatkan propaganda sebagai alat komunikasi untuk memanipulasi psikologi publik sesuai dengan kehendak mereka, dimana konten yang mereka sajikan adalah hal-hal yang negatif. Padahal sejatinya memanipulasi psikologi bisa berdampak positif atau negatif, tergantung pada konten yang disampaikan oleh individu atau kelompok (propagandis) kepada khalayak.

Menurut Suprapto dalam bukunya komunikasi propaganda (teori \& praktik) (2011) menerangkan bahwa, dalam sejarahnya tercatat bahwa propaganda pertama kali digunakan oleh Martin Luther (1483-1546) untuk menyebarkan pesan-pesan keagamaan yang justru merupakan hal yang biasa. Luther menentang kepausan dengan mengajukan argumentasi bahwa satu-satunya sumber otoritas agama adalah kitab suci itu sendiri, bukan berada pada tangan-tangan para pejabat gereja. Dari sini kita bisa tarik benang merah bahwa tujuan propaganda pertama kali digunakan untuk kepentingan Agama. Sehingga tidak berlebihan jika propaganda juga digunakan untuk kepentingan Agama Islam dalam rangka menyampaikan pesan-pesan positif. Sebab pada prinsipnya kebaikan itu harus di sampaikan, dan dalam pembahasan ini akan disusun dan diterangkan tentang pondok pesantren sebagai bagian dari lembaga pendidikan islam yang didalamnya berisi kebaikan-kebaikan, dimana kebaikan atau hal positif ini harus di sebarkan agar masyarakat menyadari tentang pentingnya keberadaan pesantren dan diharapkan minat masyarakat untuk belajar di pondok pesantren semakin meningkat.

Indonesia yang merupakan Negara dengan jumlah penduduk muslim terbesar di dunia yang didalamnya terdiri dari berbagai Suku, Ras, Agama serta Budaya, membawa Islam kedalam corak yang tersendiri dan berbeda di banding dengan negara-negara mayoritas muslim lainnya. Ke-khas-an atau keuikan tersebut tampak pula dalam dunia pendidikan Islam di Indonesia, yang salah satu produknya adalah Pondok Pesantren.

Penyelenggaraan lembaga pendidikan pesantren berbentuk asrama yang merupakan komunitas tersendiri di bawah pimpinan kyai atau ulama dibantu oleh seorang atau beberapa orang ulama, dan atau para ustadz yang hidup bersama di tengah-tengah para santri dengan masjid atau surau sebagai pusat kegiatan peribadatan keagamaan. Di samping itu, gedunggedung sekolah atau ruang- ruang belajar sebagai pusat kegiatan belajar mengajar, serta pondok-pondok sebagai tempat tinggal santri. Selama 24 jam, dari masa ke masa mereka hidup kolektif antara kyai, ustadz, santri dan para pengasuh pesantren lainnya, sebagai satu keluarga besar (Hayati, 2011). 
Pondok Pesantren merupakan salah satu tempat pendidikan agama Islam yang memiliki metode yang khas serta sistem yang sesuai dengan berbagai kondisi zaman. eksistensinya masih kuat hingga saat ini dan telah memberikan banyak sumbangsih bagi bangsa dari mulai zaman kolonial sampai era digital. Dengan realita tersebut, maka keberadaan pondok pesantren tidak dapat dipandang sebelah mata. Sejarah telah mebuktikan bahwa ditengah badai perubahan zaman dari masa ke masa tidak dapat menenggelamkan laju bahtera pendidikan Islam yang bernama pondok pesantren. Terjangan arus modernisasi tidak membuat karam sistem salafiyah di pondok pesantren, meski sebagian kalangan menganggapnya sebagai metode kuno.

Diantara banyaknya pondok pesantren yang mempertahankan sistem pendidikan tradisional dengan metode salafiyah, adapula yang bertransformasi menyesuaikan dengan tuntutan perubahan zaman. Dimana ijazah pendidikan formal menjadi sebuah tuntutan, maka banyak pula pesantren yang mendirikan sekolah formal didalamnya dengan sistem boarding school, yang kemudian dikenal dengan pondok pesantren modern. Walaupun dengan adanya istilah pondok pesantren salaf dan modern telah memunculkan polarisasi diantara keduanya, namun tidak membuat keduanya terbawa kedalam pertentangan. Semuanya tetap berjalan beriringan.

Ditengah perubahan zaman yang membuat terjadinya degradasi moral dikalangan remaja, menimbulkan keresahan diantara orang tua yang memiliki anak usia sekolah. Isu mengenai pendidikan karakter merebak, berdasarkan berbagai peristiwa yang terjadi, bahwasanya moral anak bangsa telah merosot begitu tajamnya. Hal ini disebabkan antara lain karena banyak sekolah di Indonesia hanya menjadi tempat untuk memindahkan pengetahuan baik pengetahuan secara umum maupun etika, dan belum sampai pada taraf pembentukan moral dan etika (character building) (Faiqoh dan Mahfudh 2015). Jika dipandang dengan seksama, maka sesungguhnya pesantren hadir sebagai jawaban atas permasalahan tersebut. Dimana pesantren telah menerapkan sistem pendidikan yang mengarah pada pendidikan karakter yang menitik beratkan pada akhlak atau budi pekerti. Bagi kalangan santri, kedudukan akhlak lebih utama dibanding ilmu sehingga dalam implementasinya para santri sangat mengedepankan akhlak dalam berinteraksi terutama kepada guru (kyai atau asatidz).

Namun dengan adanya fakta seperti itu, masih banyak orang yang meragukan pesantren. Beberapa faktor ditengarai sebagai penyebab kurang percayanya para orang tua untuk memondokan anaknya di pesantren. Hal inilah yang harus menjadi konsentrasi para pengelola pesantren untuk dapat kepercayaan masyarakat yang nantinya akan berimbas pada kuantitas peserta didik atau santri. 
Berbagai upaya telah dilakukan banyak pondok pesantren untuk meningkatkan kepercayaan masyarakat terhadap pesantren. Berbagai inovasi dilakukan agar dapat bersaing dengan lembaga pendidikan formal. Dari mulai penataan fisik bangunan , kurikulum pembelajaran, sampai penataan management yang lebih profesional. Akan tetapi kesemuanya itu tidak akan dapat berjalan maksimal jika masyarakat tidak mengetahui apa yang ada dalam pesantren, sehingga perlu strategi untuk menyampaikan keindahan pesantren dalam berbagai perspektif kepada masyarakat agar paradigma atau mindset mereka berubah, dari ragu menjadi yakin, dari tidak percaya menjadi percaya, dan dari tidak minat menjadi minat. Ibarat sebuah produk yang bagus, jika tanpa adanya promosi atau marketing yang baik maka tidak akan ada peminatnya. Salah satu strategi yang dianggap dapat berhasil meyakinkan publik, adalah dengan melakukan pola propaganda.

\section{Pembahasan}

\section{Teori propaganda}

Secara etimologis, propaganda berasal dari bahasa latin yakni propagare gabungan kata sifat dan kata kerja. Pro artinya forth (maju) dengan pag dari akar kata pangere (untuk mengikat) "maju untuk mengikat" yang bermakna menyebarkan (to propagate: untuk menyebarkan) informasi untuk mengikat mereka yang menerima informasi ini (Kusnandar, 2017). Secara teologis kata propagare berhubungan dengan kata propages, "a slip, a cutting of a vine" and refers to gardener's practice to disseminate plants by planting shoots. Ibarat pokok anggur yang memiliki ranting-ranting yang menghasilkan buah anggur berlimpah sebagaimana diterangkan dalam alkitab. Dengan demikian, kata propagare sering diartikan "pemikiran dan kerja terstruktur" atau dapat pula diartikan sebagai "hal yang harus disebarkan".

Seperti dijelaskan sebelumnya bahwa propaganda pertama kali digunakan oleh Martin Luther, namun mulai dikenal lebih luas setelah propaganda ini dilembagakan. Yakni setelah Paus Gregorius XV mendirikan Sacra Congregatio de Propaganda Fide (Sacred Congregation of Propaganda) pada tahun1622 yang berarti majelis suci untuk propaganda Agama. Dimana lembaga tersebut beranggotakan para Kardinal (penasihat Paus) yang ditugaskan untuk mengawasi ppenyebaran iman katholik oleh para misionaris diseluruh wilayah misi di dunia. Pusat lembaga tersebut terletak didekat Spanyol disamping Roma, hingga jalan wilayah tersebut dinamai Via de Propaganda dan tetap ada sampai saat ini.

Seiring berjalannya waktu sejarah mencatat terjadinya penyalahgunaan propaganda yang dilakukan secara masif pada masa perang dunia I dan II, dan inilah yang menyebabkan 
awal mula terjadinya distorsi makna propaganda sehingga memunculkan kesan yang buruk terhadap propaganda. Menurut Severin \& Tankard Jr (2007) hasil penelitian dan tulisan Harold khusus mengenai propaganda tercatat sebagai temuan yang sangat bernilai. Laswell meneliti khususnya pada perang dunia pertama. Ketika disertasi doctoral Harold Laswell tentang penggunaan propaganda pada perang dunia I itu dipublikasikan sebagai sebuah buku pada tahun 1927 (Propaganda Technique in the World War) banyak mendapat reaksi bahkan ada yang meminta supaya segera dihancurkan. Reaksi para pengulas menunjukkan adanya semacam ketakutan memandang tekhnik-tekhnik proganda pada perang dunia pertama.

Kemudian Adolf Hitler dan tangan kanannya Joseph Goebbels mengarahkan dunia kearah yang berbeda, tetapi juga menempatkan praktik propaganda sebagai titik lain dalam sejarah yang ikut mengubah dunia hingga saat ini. Mereka mungkin tidak menyadari kedahsyatan warisanya itu (Kusnandar, 2017).

Masih dalam Kusnandar (2017) dalam bukunya Memahami Propaganda Metode, Praktik dan Analisis menyebutkan bahwa propaganda ditangan Hitler dan Goebbels serta tokoh lain yang sezaman dengan mereka, telah berubah menjadi praktik yang sangat "mengerikan". Dengan kata lain bukan hanya karena tujuannya, tetapi juga dalam praktiknya yang kemudian mengubah dunia saat itu menjadi tempat yang sangat penuh dengan kebencian, pertentangan, pertikaian dan akhirnya menjadi tempat yang bergelimang darah. Propaganda telah menjadi momok yang sangat mengerikan atau bahkan lebih mengerikan dari perang itu sendiri.

Sejak saat itu banyak pihak yang “alergi” mendengar kata propaganda. Istilah propaganda harus ditutup rapat dalam buku kelam sejarah dunia. Bahkan banyak orang yang takut dituduh sebagai pelaku propaganda dan tentu tidak ada satupun orang yang sudi menjadi korban propaganda. Akan tetapi jika kita bertanya, apakah praktik propaganda itu masih ada atau tidak? Maka jawabannya masih. Bahkan hingga saat ini kita mungkin menjadi bagian dari penerima pesan propaganda bahkan mungkin dengan atau tanpa disadari kita juga telah menjadi bagian dari penyebar propaganda. Kendati demikian, kita juga tidak perlu takut apalagi alergi dengan istilah propaganda, sebab jika merujuk pada beberapa teori dan bukti yang disajikan oleh para ahli, propaganda itu sendiri bisa menjadi sarana untuk kegiatan yang positif. Menurut Bernays Propaganda tidak akan pernah mati. Manusia yang cerdas harus menyadari bahwa propaganda adalah instrumen modern dimana mereka bisa memperjuangkan tujuan produktif dan membantu menertibkan dunia untuk keluar dari kekacauan (Welch dalam Cull, 2003).

Harold D Laswell dalam bukunya Propaganda (1937) (dalam Suprapto, 2011) mengatakan Propaganda in broadest sense is the technique of influencing human action by manipulation of representation. Propaganda adalah tekhnik untuk mempengaruhi kegiatan mannusia dengan memanipulasikan representasinya. Ralp D. Casey mengatakan Propaganda adalah suatu usaha 
yang dilakukan secara sengaja dan sadar untuk memantapkan suatu sikap atau merupakan suatu pendapat yang berkaitan dengan suatu doktrin atau program dan di pihak lain merupakan usaha yang sadar dari lembaga-lebaga komunikasi untuk menyebarkan fakta dalam semangat objektivitas dan kejujuran.

Edward Bernays menggambarkan propagada sebagai suatu usaha yang konsisten untuk menciptakan atau membentuk suatu peristiwa agar peristiwa itu dapat mempengaruhi relasi dikalangan publik dengan suatu ide tertentu kelompok, organisasi atau perusahaan (Bernays, 1928). Sementara itu Marcel Danesi mendefinisikan propaganda adalah sekumpulan bahan, strategi, baik terang-terangan atau terselubung yang digunakan untuk menyebarkan terutama ideologi atau pendapat, dalam rangka untuk membujuk atau meyakinkan orang lain akan kebenaran pendapat atau ideologinya itu (Danesi, 2009).

Dengan demikian dapat disimpulkan bahwa sesungguhnya propaganda dapat dipandang dalam berbagai perspektif. Baik itu perspektif Agama, politik, ideologi, ekonomi, psikologi dan sebagainya. Kemudian kita dapat menggunakan propaganda sesuai kebutuhan sebagai sarana menyebarkan pesan dengan menggunakan produksi komunikasi yang telah dirancang untuk dapat mempengaruhi pikiran, psikologi dan emosi publik agar bisa sependapat dengan isi atau konten yang kita sebarkan.

\section{Sejarah dan tipe Pesantren}

Pesantren sesungguhnya merupakan lembaga pendidikan tertua di Indonesia, yang secara nyata telah melahirkan banyak ulama'. Tidak sedikit tokoh Islam lahir dari lembaga pesantren. Bahkan Prof.Dr.Mukti Ali pernah mengatakan bahwa tidak pernah ada ulama yang lahir dari lembaga selain pesantren. Istilah "pesantren" berasal dari kata pe-"santri"-an, dimana kata "santri" berarti murid dalam bahasa Jawa. Istilah "pondok" berasal dari bahasa Arab "funduuq" ("'فندوق "') yang berarti penginapan. Khusus di Aceh, pesantren disebut juga dengan nama "dayah" (Syafe'i, 2017). Masih menurut Syafe'i (2017) menerangkan bahwa, biasanya pesantren dipimpin oleh kyai. Untuk mengatur kehidupan pesantren, kyai menunjuk seorang

santri senior untuk mengatur adik-adik kelasnya, mereka biasanya dalam pesantren salaf (tradisional) disebut "lurah pondok". Tujuan santri dipisahkan dari orang tua dan keluarga mereka agar mereka belajar hidup mandiri, dapat meningkatkan hubungan yang baik dengan kyai dan juga Tuhan. Ada beberapa elemen pesantren yang membedakan dengan lembaga lainnya, yaitu; (1) pondok tempat menginap para santri, (2) santri: peserta didik, (3) masjid: sarana ibadah dan pusat kegiatan pesantren, (4) kyai: tokoh atau sebutan seseorang yang memiliki kelebihan dari sisi agama, dan kharisma yang dimilikinya, (5) kitab kuning: sebagai 
referensi pokok dalam kajian keislaman (Dhofier, 1982). Awal munculnya pesantren, pembelajarannya bersifat nonklasikal, dimana seorang kyai mengajarkan agama Islam yang ditulis pada abad pertengahan (Prasidjo \& Al, 2001).

Dalam jurnalnya yang berjudul Pondok Pesantren: Lembaga pendidikan pembentuk karakter, Syafe'i (2017) juga menuliskan Sekarang ini banyak ditemukan model-model pesantren di Indonesia yang nyaris berbeda desain bangunannya dengan pesantren-pesantren klasik. Menurut Manfred Ziemek, maka tipe-tipe persantren di Indonesia dapat digolongkan sebagai berikut.

1. Tipe A, yaitu pondok pesantren yang seluruhnya dilaksanakan secara tradisional, dalam arti tidak mengalami transformasi yang berarti dalam sistem pendidikannya atau tidak ada inovasi yang menonjol dalam corak pesantrennya dan masih tetap eksis mempertahankan tradisi-tradisi pesantren klasik dengan corak keislamannnya berdasarkan peraturan menteri Agama Nomor 3 Tahun 1979 tentang Bantuan kepada Pondok Pesantren dalam (Makmun, 2014). Masjid digunakan untuk pembelajaran Agama Islam disamping tempat shalat. Tipe ini biasanya digunakan oleh kelompokkelompok tarikat dan disebut pesantren tarikat. Para santri pada umumnya tinggal di asrama yang terletak di sekitar rumah kyai atau di rumah kyai. Tipe ini sarana fisiknya terdiri dari masjid dan rumah kyai, pada umumnya dijumpai awal-awal berdirinya pesantren (Ziemek, 1986).

2. Tipe B, pesantren yaitu yang mempuyai sarana fisik, seperti; masjid, rumah kyai, pondok atau asrama yang disediakan bagi para santri, utamanya adalah dari daerah jauh, sekaligus menjadi ruangan belajar. Tipe ini adalah pesantren tradisional yang sangat sederhana sekaligus merupakan ciri pesantren tradisional (Ziemek, 1986). Sistem pembelajaran pada tipe ini adalah individual (sorogan), bandungan, dan wetonan.

3. Tipe $\mathrm{C}$, atau pesantren salafi ditambah dengan lembaga sekolah (madrasah, SMU atau kejuruan) merupakan karakteristik pembaharuan dan modernisasi pendidikan Islam di pesantren. Meskipun demikian, pesantren tidak menghilangkan sistem pembelajaran yang asli yaitu sistem sorogan, bandungan, dan wetonan yang dilakukan oleh kyai atau ustadz (Prasidjo \& Al, 2001).

4. Tipe D, yaitu pesantren modern terbuka untuk umum, corak pesantren ini telah mengalami transformasi yang sangat signifikan baik dalam sistem pendidikan maupun unsur-unsur kelembagaannya. Materi dan sistem pembelajaran sudah menggunakan sistem modern dan klasikal. Jenjang pendidikan yang diselenggarakan mulai dari 
tingkat dasar (PAUD dan TK) sampai pada perguruan tinggi. Tipe ini sangat memperhatikan terhadap mengembangkan bakat dan minat santri sehingga santri bisa mengeksplor diri sesuai bakat dan minat (Nizar, 2007). Hal yang tidak kalah penting adalah keseriusan dalam penguasaan bahasa asing, baik bahsaa Arab dan Inggris maupun bahasa internasional lainnya. Contohnya, pesantren Gontor, Tebuireng dan pesantren modern lainnya yang ada di tanah air.

5. Tipe E, yaitu pesantren yang tidak memiliki lembaga pendidikan formal, tetapi memberikan kesempatan kepada santri untuk belajar pada jenjang pendidikan formal di luar pesantren. Pesantren tipe ini,dapat dijumlai pada pesantren salafi dan jumlahnya di nusantara relatif lebih kecil dibandingkan tipe-tipe lainnya.

6. Tipe $\mathrm{F}$, atau ma'had 'Aly, tipe ini, biasanya ada pada perguruan tinggi agama atau perguruan tinggi bercorak agama. Para mahasiswa di asramakan dalam waktu tertentu dengan peraturan-peraturan yang telah ditetapkan oleh perguruaan tinggi,m ahasiswa wajib mentaati peraturan-peraturan tersebut bagi mahasiswa yang tinggal di asrama atau ma'had. Sebagai contoh, ma'had 'aly UIN Malang yang telah ada sejak tahun 2000 dan semua mahasiswa wajib diasramakan selama satu tahun. Kemudian ma'had 'aly IAIN Raden Intan Lampung yang telah berdiri sejak 2010 yang lalu. Tujuan dari ma'had 'aly tersebut adalah untuk memberikan pendalaman spiritual mahasiswa dan menciptakan iklim kampus yang kondusif untuk pengembangan bahasa asing ("Visi, Misi dan Tradisi UIN Maulana Malik Ibrahim Malang,” 2012).

Dari tipe serta karakteristiknya yang telah di jelaskan diatas, maka pondok pesantren AlKhoeriyah Cibingbin termasuk kedalam pesantren dengan tipe D. Dimana pola pembelajarannya gabungan dari modern-klasikal. Pondok pesantren Al-Khoeriyah memiliki dua program pembelajaran, yakni program SMP Islam Terpadu dan program Takhosus Tahfidz Al-Qur,an.

Program SMP Islam Terpadu menggunakan kurikulum Standar Nasional Pendidikan yang ditambah dengan beberapa mata pelajaran pesantren, yakni kitab-kitab klasik (kitab kuning) dan hafalan Al-Qur'an. Sementara untuk program takhosus tahfidzul Qur'an menggunakan kurikulum hafalan Qur'an dengan metode Yanbu'a dan metode tiqraar. Pada kedua program tersebut juga diwajibkan untuk belajar Bahasa Arab dan Inggris serta pengembangan diri dengan metode multiple intellegences. 


\section{Teknik propaganda di Pesantren Al-Khoeriyah}

Propaganda memiliki 7 tekhnik, yaitu Name Calling,Gittering generalities, Transfer, Testimonial, Plain Folk, Card Stacking, dan Band Wagon. Namun dalam mempromosikan lembaganya, pihak Pondok Pesantren al-khoeriyah tidak menggunakan pola propaganda secara keseluruhan, karena ada teknik yang dianggap tidak pantas digunakan oleh pihak pesantren. Adapun teknik yang digunakan, diantaranya:

1. Name Calling

Name calling adalah pemberian label buruk pada suatu gagasan, dipakai untuk membuat kita menolak dan mengutuk ide tanpa mengamati bukti (Lee \& Lee dalam Severin \& Tankard, 2011). Propaganda ini biasa digunakan untuk menyerang lawan yang dianggap musuh dalam ideologi, teologi atau politik. Sebagai contoh yang paling sering menggunakan teknik ini adalah Negara Amerika yang gemar menjuluki Negara yang tak berpihak padanya sebagai teroris, disisi lain mereka yang membuat perang di beberapa Negara timur tengah menyebut dirinya sebagai aksi penyelamatan atas terorisme. Teknik ini jelas tidak pantas untuk digunakan dalam promosi pondok pesantren.

2. Glittering Generalities

Glittering generalities adalah teknik propaganda yang berusaha menghubungkan seseuatu dengan "kata yang baik" dipakai untuk membuat kita menerima dan menyetujui sesuatu tanpa memeriksa bukti-bukti (Lee \& Lee dalam Severin \& Tankard, 2011). Dengan kata lain teknik ini menggunakan cara mengangkat nama sendiri dengan kata-kata yang baik. Glittering generalities paling banyak digunakan dalam pemasaran produk atau iklan. Contoh yang banyak diketahui oleh kita misalnya produk jamu tolak angin "orang pintar minum tolak angin", lalu ada produk tekhnologi bernama Nokia "tekhnologi yang mengerti anda", dan banyak lagi yang lainnya.

Terkait hal tersebut diatas, maka teknik ini bisa digunakan untuk propaganda pesantren. Secara umum pesantren sendiri memiliki glittering generalities yang sudah lama dikenal, yakni “Ayo mondok". Kata yang bersifat persuasi atau ajakan ini adalah propaganda yang banyak orang tidak menyadarinya. Berangkat dari situ, pondok pesantren Al-Khoeriyah kemudian membuat glittering generalities dengan kalimat "Berilmu dan berakhlakul karimah". Kalimat ini kemudian dikenalkan dan disebarkan melalui tagar di medsos secara masif. Tagar tersebut seperti ini, \#alkhoeriyah \#berilmudanberakhlakulkarimah. 
3. Transfer

Transfer adalah teknik propaganda dengan cara membawa otoritas, dukungan dan gengsi dari sesuatu yang dihargai dan disanjung kepada sesuatu yang lain agar sesuatu yang lain itu dapat diterima (Lee \& Lee dalam Severin \& Tankard, 2011). Transfer bekerja melalui proses asosiasi. Tujuan komunikator adalah menghubungkan gagasan atau produk dengan sesuatu yang dikagumi orang. Dalam hal membawa otoritas, dukungan dan gengsi, kita dapat mengingat iklan produk tolak angin yang menggunakan tokoh besar yakni Dahlan Iskan, selain pada saat itu berpengaruh karena menjabat sebagai menteri BUMN beliau juga di asosiasikan sebagai orang pintar, sehingga khalayak akan terpengaruh oleh teknik propaganda ini. Al-khoeriyah sendiri menggunakan teknik ini dengan cara menggunakan pembina Yayasannya sebagai tokoh dari kalangan ulama yakni DR. KH. Ja'far Aththoyyar, Lc, MA dimana beliau sebagai ulama lulusan Universitas Al-Ahqaff, Yaman yang telah berpengalaman dalam dunia pesantren selama lebih dari 20 tahun sehingga akan diasosiasikan sesuai dengan jargon pesantren Al-khoeriyah yakni berilmu dan berakhlakul karimah. Selain itu Al-Khoeriyah juga kerap menghadirkan ulama-ulama besar baik dari dalam maupun luar negeri dalam rangka mengisi kegiatan untuk meningkatkan gengsi lembaga.

Kemudian teknik transfer juga mengunakan simbol-simbol tertentu untuk menggiring psikologi publik kearah asosiatif, sehingga ketika melihat simbol tertentu akan langsung mengingat kepada pihak yang menyebarkan atau memiliki simbol tersebut. Misalnya ketika kita melihat simbol bintang dan warna hijau maka asosiasinya adalah Nahdlatul Ulama, atau misalnya dalam produk rokok dengan Dji Sam Soe menggunakan simbol "234", dan sebagainya. Sedangkan pesantren Al-Khoeriyah menggunakan simbol yang selalu digunakan dalam setiap unggahan medsos, cetakan pamflet, slide video dan sebagainya.

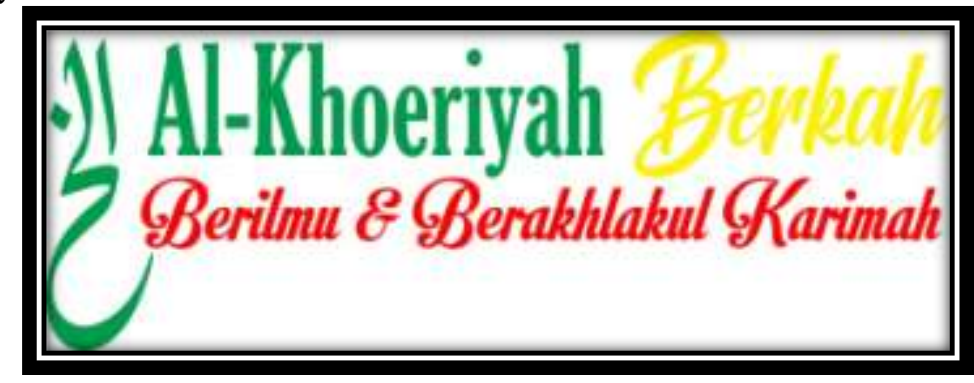

Gambar 1.

Teknik propaganda "transfer" dalam bentuk simbol

Yang digunakan Pondok Pesntren Al-Khoeriyah 


\section{Testimonial}

Testimonial (kesaksian) adalah teknik propaganda dengan cara memberi kesempatan pada orang-orang yang mengagumi atau membenci untuk mengatakan bahwa sebuah gagasan atau program atau produk atau seseorang itu baik atau buruk (Lee \& Lee dalam Severin \& Tankard, 2011). Teknik ini biasa digunakan dalam kampanye politik atau periklanan. Dalam periklanan biasa dikenal dengan istilah Brand Ambassador atau duta produk. Di era industri 4.0 sekarang ini, sudah menjadi hal lumrah jika sebuah produk di buatkan testimoni oleh seorang influencer atau orang yang dianggap terkenal di media sosial terutama Instagram, Facebook dan Youtube, cara ini lebih dikenal dengan sebutan endorsement. Misalnya produk kopi gilus dari torabika menggunakan beberapa youtuber terkenal seperti Andre Taulany dan Deddy Corbuzier, dimana dalam konten-kontennya mereka mempromosikan produk tersebut. Teknik ini juga digunakan oleh pesantren Al-Khoeriyah dengan menampilkan foto dan vidio testimoni para santri yang sudah selesai atau mengkhatamkan hafalan Al-Qur'an 30 juz. Sehingga ini meyakinkan khalayak terhadap kwalitas pendidikan di Pesantren Al-Khoeriyah.

\section{Plain Folks}

Plain Folks adalah teknik propaganda yang dipakai oleh pembicara dalam upayanya meyakinkan khalayak bahwa dia dan gagasannya bagus karena mereka adalah "bagian dari rakyat" dan rakyat yang lugu (Lee \& Lee dalam Severin \& Tankard, 2011). Dengan kata lain teknik ini semacam berbaur dengan masyarakat, sehingga antara propagandis dengan masyarakat memiliki ikatan persamaan dan tidak ada jarak diantara keduanya serta lebih jauhnya masyarakat akan menganggap propagandis adalah bagian dari mereka. Teknik ini paling sering digunaka oleh para politisi untuk meraup suara dengan cara berbaur dengan masyarakat agar menimbulkan kesan merakyat. Dan ini seringkali berhasil, karena kebanyakan masyarakat mengharapkan memiliki pemimpin atau anggota dewan yang merupakan representatif dari mereka, sekalipun pada kenyataannya berbanding terbalik dari apa yang di asumsikan masyarakat.

Teknik ini juga dapat digunakan untuk mendekatkan hubungan emosional antara pihak pondok pesantren dengan masyarakat. Seperti yang dilakukan oleh pondok pesantren Al-Khoeriyah, dimana pesantren memiliki Lembaga Pengembangan Dakwah (LPD) yang khusus menangani dakwah ke masyarakat luas, serta melaksanakan berbagai 
aktifitas sosial seperti penanganan bencana, khitanan massal, tebar hewan qurban, bahkan nikah massal yang kesemuanya rutin diadakan setiap tahun. Masyarakat yang pernah terlibat akan merasakan ikatan batin dengan Al-Khoeriyah, namun terlepas dari teknik propaganda ini, pada dasarnya LPD Al-Khoeriyah dibentuk dalam rangka menjalankan perintah Rasulullah untuk menjadi manusia yang bermanfaat untuk manusia lainnya.

\section{Card Stacking}

Card stacking adalah upaya pemulihan dan pemanfaatan fakta atau kebohongan, ilustrasi atau penyimpangan dan pernyataan-pernyataan logis atau tidak logis untuk memberikan kasus terbaik atau terburuk pada sebuah gagasan, program, orang atau produk (Lee \& Lee dalam Severin \& Tankard, 2011). Card stacking pada dasarnya sama dengan slanting dalam ilmu semantik umum. Teknik ini memilih argumen atau bukti yang mendukung sebuah posisi dan mengabaikan hal-hal yang tidak mendukung posisi itu. Argumen-argumen bisa benar atau salah. Cara ini mungkin akan berjalan efektif jika argumen tersebut benar, tetapi argumen-argumen benar lainnya diabaikan (Kunandar, 2017). Teknik ini tidak digunakan dalam pola propaganda promosi pondok pesantren Al-Khoeriyah karena dianggap kurang layak.

7. Bandwagon

Bandwagon memiliki tema setiap orang-paling tidak kita semua - sedang melakukannya. Dengan begitu, para pelaku propaganda berusaha meyakinkan kita bahwa semua anggota suatu kelompok dimana kita menjadi anggotanya menerima programnya dan oleh karena itu harus mengikuti kelompok kita dan menggabungkan diri dalam kelompok itu (Lee \& Lee dalam Severin \& Tankard, 2011). Bandwagon yang berasal dari kata gerbong kereta, berarti bahwa teknik propaganda ini mengharapkan khalayak untuk ikut pada perspektif yang dibangun oleh propagandis. Jika ada pesan yang disebarkan oleh propagandis, maka bagi pihak yang sudah merasa bagian didalamnya akan turut serta menyebarkan pesan tersebut. Kalimat-kalimat dalam propaganda ini ajakan yang kuat untuk bergabung.

Bandwagon sendiri memiliki dua tipe, pertama inevitable victory yakni mengajak untuk segera bergabung menuju "kemenangan atau kebaikan" sebeleum tertinggal atau terlambat. Dan yang kedua adalah join the crowd dimana teknik ini digunakan untuk memperkuat keinginan alami manusia untuk berada dipihak yang menang atau baik. 
Di Pondok Pesantren Al-Khoeriyah, teknik ini digunakan agar promosi semakin menyebar luas dengan bantuan para partisipan dan sukarelawan. Dengan menggunakan kalimat "kami menunggu anda untuk menjadi bagian dari keluarga kami” akan memunculkan kesan bahwa setiap yang ada keterkaitan dengan pesantren Al-Khoeriyah akan merasa dirinya sebagai bagian dari keluarga, yang harus saling membantu. Dan akan lebih menarik khalayak untuk bisa bergabung dengan cara mondok di pesantren Al-Khoeriyah.

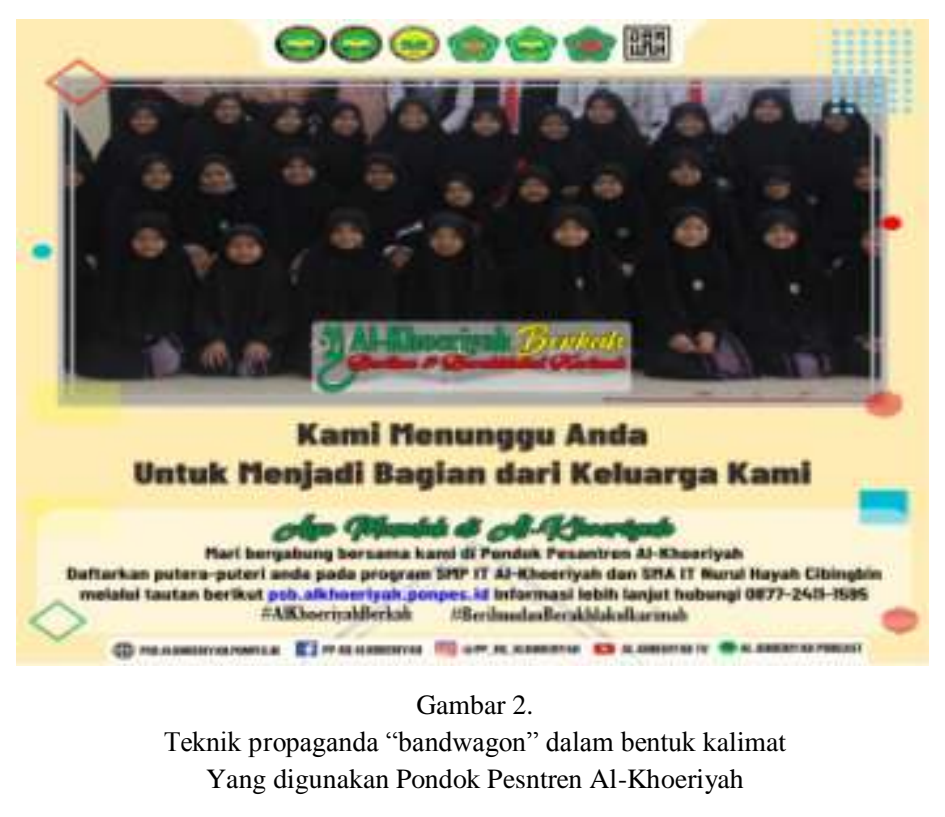

\section{KESIMPULAN}

Dari keterangan yang telah dijabarkan maka dapat disimpulkan bahwa propaganda adalah alat komunikasi biasa yang memiliki dua sisi, yakni baik dan buruk. Seperti layaknya pisau yang hanyalah sebuah alat yang bisa menjadi baik atau buruk, tergantung siapa yang menggunakannya. Jika digunakan oleh penjahat maka akan sangat merugikan, namun jika ditangan seorang juru masak tentu akan sangat menguntungkan. Persepsi masyarakat terhadap proppaganda hendaknya berubah, tidak selalu berpikiran negatif, akan tetapi dapat mengambil sisi positifnya. Kita sebagai manusia harus mampu untuk dapat mencari celah yang bisa membawa dampak positif. Seperti pribahasa China yang berbunyi "When storm comes, some build wall, but some build windmill" ketika badai datang, sebagian orang membangun benteng, namun sebagian lainnya membangun kincir angin. Pondok pesantren Al-khoeriyah berusaha untuk menjadi golongan yang membangun kincir angin, agar dapat manfaat dari 
sesuatu yang bahkan terkesan buruk. Dalam hal ini Pondok pesantren Al-Khoeriyah berusaha menyebarkan pesan untuk mempengaruhi psikologi publik untuk mendapatkan minat yang tinggi, namun tetap memperhatikan batas yang wajar dan normal serta tidak berlebihan. Yakni dengan menggunakan informasi yang sebenarnya, atau menyampaikan fakta dan realita yang dikemas dengan menarik.

\section{DAFTAR PUSTAKA}

Bernays, E. (1928). Propaganda. Brooklyn: Ig Publishing.

Danesi, M. (2009). Dictionary of Media Communication. New York: N.E. Shape.

Dhofier, Z. (1994). Tradisi Pesantren: Studi tentang Pandangan Hidup Kyai. Jakarta: LP3ES.

Faiqoh, \& Mahfudh, S. (2015). Model Pembentukan Karakter Religius Santri Tahfidz Al-Qur'an di Pondok Pesantren Mathali'ul Huda Pusat Kajen Pati. EDUKASI: Jurnal Penelitian Pendidikan Agama Dan Keagamaan, 13(3).

Hayati, F. (2011). Pesantren sebagai Alternatif Model Lembaga Pendidikan Kader Bangsa. MIMBAR, XXVII(2).

Kunandar, A. (2017). Memahami Propaganda Metode, Praktik, dan Analisis. Yogyakarta: Kanisius.

Makmun, H. A. R. (2014). Pembentukan Karakter Berbasis Pendidikan Pesantren: Studi di Pondok Pesantren Tradisional dan Modern Di Kabupaten Ponorogo. Cendekia Vol., 12(2).

Nizar, S. (2007). Sejarah Pendidikan Islam: Menelusuri Jejak Sejarah Pendidikan Era Rasulullah Sampai Indonesia. Jogjakarta: Prenada Media Group.

Prasidjo, S., \& Al, E. (2001). "Profil Pesantren", dalam Abudin Nata (editor), Sejarah Pertumbuhan dan Perkembangan lembaga-Lembaga Pendidikan Islam di Indonesia. Jakarta: Grasindo.

Severin, W. J. \& Tankard Jr., James W. (2011). Teori Komunikasi, Sejarah, Metode, dan Terapan di Dalam Media Massa, Edisi ke-5, Dialih bahasakan oleh Sugeng Hariyanto, Jakarta: Kencana.

Suprapto, T. (2011). Komunikasi Propaganda (Teori dan Praktik). Yogyakarta: CAPS.

Syafe'i, I. (2017). Pondok Pesantren: Lembaga Pembentukan Karakter. Al-Tadzkiyyah: Jurnal Pendidikan Islam, Volume 8, No I.

Ziemek, M. (1986). Pesantren Dalam Perubahan Sosial. Jakarta: P3M. 